\title{
Mathematics Preservice Trainee Teachers' Perceptions of Attention to Diversity in Initial Training as Secondary Education Teachers
}

\author{
María Jesús Caurcel Cara ${ }^{1}$ (D), Emilio Crisol Moya ${ }^{2, *(D)}$ and Carmen del Pilar Gallardo-Montes ${ }^{2}$ (D) \\ 1 Department of Developmental and Educational Psychology, Faculty of Education, University of Granada, \\ 18071 Granada, Spain; caurcel@ugr.es \\ 2 Department of Didactics and School Organization, University of Granada, 18071 Granada, Spain; \\ cgallardo@ugr.es \\ * Correspondence: ecrisol@ugr.es; Tel.: +34-958-243-987
}

check for

updates

Citation: Caurcel Cara, M.J.; Crisol Moya, E.; Gallardo-Montes, C.d.P. Mathematics Preservice Trainee Teachers' Perceptions of Attention to Diversity in Initial Training as Secondary Education Teachers. Mathematics 2021, 9, 1697. https:/ / doi.org/10.3390/math9141697

Academic Editor: Christopher C. Tisdell

Received: 1 June 2021

Accepted: 14 July 2021

Published: 19 July 2021

Publisher's Note: MDPI stays neutral with regard to jurisdictional claims in published maps and institutional affiliations.

Copyright: (c) 2021 by the authors. Licensee MDPI, Basel, Switzerland. This article is an open access article distributed under the terms and conditions of the Creative Commons Attribution (CC BY) license (https:/ / creativecommons.org/licenses/by/ $4.0 /)$.

\begin{abstract}
Research on teachers' perceptions about diversity is key to understanding the different approaches to be implemented to build inclusive education. Within this framework, the perceptions and attitudes of 73 students in the Mathematics specialization of the University Master's Degree in Teacher Training for Secondary Education, Bachillerato, Vocational Training and Language Teaching (Máster Universitario en Profesorado de Educación Secundaria Obligatoria, Formación Profesional y Enseñanza de Idiomas (MAES) at the University of Granada (Spain) were analyzed to determine their views about the initial training they received on attention to diversity during the Master's program. The study is a descriptive and correlational-predictive transversal examination of the responses obtained from the "Questionnaire for preservice secondary education teachers on perceptions about attention to diversity" (Colmenero Ruiz and Pegalajar Palomino, 2015). The findings demonstrate that the students-preservice secondary education teachers—-held favorable attitudes toward diversity and the principle of inclusion. The findings also show that contact with persons with disability influences perception of this population. The authors conclude that better training and knowledge of the elements that condition the teaching-learning process for high-quality attention to diversity predict better pedagogical preparation in matters of attention to diversity.
\end{abstract}

Keywords: student; training; inclusive education; special educational needs; perception; graduate

\section{Introduction}

Attention to diversity is an influential issue in schools' quality systems. This attention represents the school's capability to meet the specific needs of the educational community [1] and is conceived as one way to achieve social equality [2,3].

In the context of secondary education, the teacher is the key agent in building a high-quality inclusive school [4-7].

A country's system for training mathematics professors (its policies, institutions, programs, etc.) is the product of a specific tradition and history linked to the country's context. In some cases, such as that of the Spanish system, training programs are highly varied. For example, in Spain, most people who decide to be secondary education mathematics teachers have earned a Bachelor's in Mathematics (4 years) and taken a pedagogical qualification course.

The University of Granada (UGR) (Spain), the context for this study, has extensive experience in initial and continuing education for teachers at all stages of education [8]. Its preservice training for compulsory secondary education has been organized around a University Master's Degree in Teacher Training for Secondary Education, Bachillerato, Vocational Training and Language Teaching (Máster Universitario en Profesorado de Educación Secundaria Obligatoria y Bachillerato, Formación Profesional y Enseñanza de 
Idiomas (MAES)). For matters of educational inclusion, the MAES includes objectives such as developing and implementing individual and group didactic methods adapted to the students' diversity, and designing and developing learning environments with special attention to equity [8].

Recent studies have shown that preservice training in attention to diversity is a determining factor in the success of inclusive education [9-12]. This training improves preservice teachers' attitudes and confidence, and reduces their concerns about inclusion [4,6,13-15]. It also helps to improve their skills and self-reflection on their skills for attention to diversity [16]. Some authors [17-20] thus stress that preservice teachers perceive the importance of preparing secondary education teachers trained in both curriculum and affective issues, as well as skills related to diversity. These authors express dissatisfaction with the amount of time dedicated to preservice teachers' didactic training, the connection between theory and practice, and coordination among teachers.

Attending to diversity in mathematics is a complex task. Teaching mathematics in the context of school inclusion is a challenge for the education system in every country. The initial introduction to formal contents with a high level of abstraction in a context of students with special educational needs involves a change in the way these contents are presented $[21,22]$.

\section{Review of Related Literature}

Studying preservice teachers' perceptions of diversity is key to understanding the different approaches that must be put into practice in the educational context [23]. Teachers work with different kinds of knowledge. The first kind is explicit knowledge [24], which includes knowledge of what to do, how to do it, and why one does it [25]. The second kind, tacit knowledge [26], is based on internalization through experience and/or observation of events. Tacit knowledge is neither shared nor communicated.

Thoughts, intuitions, expectations, and perceptions form part of tacit knowledge. In this study, perceptions are defined as a conceptual foundation that plays an important role in thinking and future action. As such, they provide perspectives on the world and concept organizers [25].

It is crucial to consider perceptions as a set of positions that teachers have about their practice that correspond to issues related to teaching and learning. We focus on teachers' positions on the different variables that make up the educational training they receive on attention to diversity to achieve inclusive high-quality education.

Preservice training of secondary education teachers is an important focus of attention in all European countries. In Spain, educational reforms have been transforming education, requiring teachers to assume new tasks and responsibilities that involve them in the school's functioning [8].

The literature review indicates that most teachers support inclusion, although their conviction decreases when they must become involved in the process [2,27-34]. Authors such as Avramidis and Kalyva [35] and Pegalajar Palomino and Colmenero Ruiz [36] show that teachers affirm holding positive attitudes toward inclusion, although they prefer to have a special education teacher present in the classroom or to have the student with special educational support needs (SNES) continue to receive services in the special education classroom.

Forlin and Chambers [16], Sharma et al. [12], Da Silva [37] and Struyven [20] argue that attitudes toward attention to diversity improve among graduate students, who are more qualified, as they advance in their education. Along these lines, other studies [1,38-42] show that the training of secondary education teachers is insufficient, especially in attention to underperforming students, lack of motivation toward studies [43], anti-social or unhealthy behavior, or school bullying. Studies by Sandoval Mena [44] and Smets and Struyven [20] find educational gaps in identification of learning difficulties, teachers responsibilities, and cooperation among teachers. These gaps concerning attention to 
diversity can create feelings of disorientation, vulnerability, incompetence, lack of interest and even rejection $[22,45,46]$.

Studies show $[10,20,42]$ that not only specific training but also contact with persons with disabilities or disorders increases positive attitudes toward this population [47-50]. Direct contact and information are the foundation for building and changing beliefs and then behavior $[19,51,52]$.

The literature review also enables identification of the relationship between attention to diversity and specific sociodemographic traits of in-service and/or preservice teachers. The results on gender are inconsistent. Alghazo and Naggar [53] observe less-positive attitudes toward educational inclusion among male teachers, whereas Batsiou et al. [54] find that male teachers have more positive attitudes. Opdal et al. [55] argue that female teachers promote more inclusive teaching practices. These results contradict those of Hodge et al. [56], Kudláèek et al. [57], Parasuram [51], and Flores and Villardón [15], who do not find significant gender-based differences in general attitude.

As for teaching experiences, studies show that teachers with more classroom experience usually show more positive attitudes to the development of inclusive practices than do less-experienced teachers $[9,58]$. Alghazo and Naggar [53], in contrast, show that teachers with up to five years of teaching experience develop more positive practices for inclusion than do teachers with six or more years of experience. Along these lines, Glaubman and Lifshitz [59] have shown that teachers with fewer years of experience (up to 10 years) implement more inclusive practices than do their more senior counterparts (more than 11 years). It thus seems possible to determine, as Avramidis et al. [60] and Hastings and Oakford [61] show, that years of teaching experience are not related to teachers' attitudes.

In discussing teaching mathematics to students with SNES, we think first of the challenges mathematics teachers face at all educational levels. First, mathematics teaching is inherently a challenge for teachers at all levels of education due to the difficulties mathematics has represented for learners over time. The strict rigor of the discipline, especially in secondary and subsequent education levels, is one of the factors that makes significant learning of mathematics concepts difficult. Second, and most importantly, much research and many of the recommendations in mathematics education in recent years has focused on students' conceptual understanding and competence with mathematical processes [31,62-66].

Studies focus primarily on defining the knowledge and competences required of mathematics teachers at any level to handle teaching the discipline [67], without explicitly treating knowledge related to educational inclusion and special educational needs. This body of research reveals a lack of studies on how to treat mathematics teachers' training to work with students with special educational needs [62]. Third, traditional mathematics learning environments are not designed for students with disabilities [67] and thus create learning barriers [68], defining students only through their deficiencies [67].

To advance knowledge in this field, this study analyzes the attitudes and perceptions of attention to diversity among students in the mathematics specialization of the MAES; that is, preservice secondary education teachers.

The goals of this study are: (a) to describe the perceptions and attitudes toward attention to diversity that these students experience; (b) to analyze the possible relationships among the different factors that determine attitudes and perceptions of attention to diversity; (c) to define differences based on sociodemographic variables and variables related to the participants: age, sex, gender, disability, type of disability, contact with persons with disabilities and/or disorders, frequency of that contact and quality of contact; and (d) to confirm the predictive character of Factors I, II, IV and V for pedagogical training in attention to diversity. 


\section{Materials and Methods}

\subsection{Participants}

The study population was composed of 88 students enrolled in the mathematics specialization of the UGR's MAES during academic years 2018/2019 $(N=44)$ and 2019/2020 ( $N=44$ ). Simple probabilistic random sampling was used to select the sample [69], such that all subjects who answered the questionnaire were randomly included in the sample $(N=73)$. The sample obtained a $95 \%$ confidence level and a margin of error below $4.8 \%$, according to the mathematical calculations of representative sample size (http: / www. adimen.es/calculadora-muestras.aspx) (accessed on 14 June 2021). This value is slightly below the lowest error limit usually used in Education research (5\%).

The participants were taking the required subject "Educational processes and contexts" from the general module taught by two professors from the Department of Didactics and School Organization. Of the total sample, $47.9 \%(N=35)$ took the course with Professor A, who had six and seven years of experience teaching in the MAES (academic years 2018/2019 and 2019/2020, respectively); and 52.1\% ( $N=38)$ with Professor B, who had two and three years of experience teaching in the MAES (for 2018/2019 and 2019/2020, respectively).

The students' ages ranged from 22 to 50 years $(\mathrm{M}=27.12, \mathrm{SD}=6.45) ; 35$ were women and 38 men. The sample was nearly balanced by sex. Table 1 presents the sociodemographic, academic and relational data of the sample of students. None of the students had a serious sensory-perceptual or motor disability that prevented them from completing the assessment instruments themselves.

Table 1. Sociodemographic, academic and relational data of the 73 students evaluated.

\begin{tabular}{|c|c|c|}
\hline \multicolumn{2}{|c|}{ Variables } & \multirow{2}{*}{$\frac{N(\%)}{35(47.9)}$} \\
\hline & $18-19$ & \\
\hline Academic year & $19-20$ & $38(52.1)$ \\
\hline \multirow{3}{*}{ Age } & 22-24 years & $36(49.3)$ \\
\hline & $25-27$ years & $17(23.3)$ \\
\hline & Over 28 years & $20(27.4)$ \\
\hline \multirow{3}{*}{ Sex } & Women & $35(47.9)$ \\
\hline & Men & $38(52.1)$ \\
\hline & Others & $0(0)$ \\
\hline \multirow{3}{*}{ Gender } & Female & $35(47.9)$ \\
\hline & Male & $38(52.1)$ \\
\hline & Other & $0(0)$ \\
\hline \multirow{2}{*}{ Disability } & No & $41(56.2)$ \\
\hline & Yes & $32(43.3)$ \\
\hline \multirow{6}{*}{ Type of disability } & Behavioral & $16(50.0)$ \\
\hline & Visual & $9(28.1)$ \\
\hline & Emotional & $3(9.4)$ \\
\hline & Mental & $2(6.3)$ \\
\hline & Eating & $1(3.1)$ \\
\hline & Written Language & $1(3.1)$ \\
\hline \multirow{2}{*}{$\begin{array}{l}\text { Contact with persons with } \\
\text { disabilities and/or disorders }\end{array}$} & No & $29(33.7)$ \\
\hline & Yes & $44(66.3)$ \\
\hline \multirow{4}{*}{ Frequency of contact } & Almost never & $3(6,8)$ \\
\hline & Rarely & $16(36.4)$ \\
\hline & Often & $19(43.2)$ \\
\hline & Very often & $6(43.2)$ \\
\hline
\end{tabular}


Table 1. Cont.

\begin{tabular}{lcc}
\hline & Variables & $N(\%)$ \\
\hline & Very negative & $0(0)$ \\
& Negative & $1(2.3)$ \\
Quality of contact & Neutral & $13(29.5)$ \\
& Positive & $21(47.7)$ \\
& Very positive & $8(20.5)$ \\
\hline
\end{tabular}

\subsection{Variables and Instruments}

The "Questionnaire for preservice secondary education teachers on perceptions about attention to diversity" by Colmenero Ruiz and Pegalajar Palomino [70] was used to assess attitudes and perceptions about attention to diversity. The questionnaire consisted of 43 items with a Likert-type response scale ranging from 1 (Strongly agree) to 4 (Strongly disagree). The scale was composed of a global scale and five subscales: "Elements conditioning the process of attention to diversity in the classroom" (Factor I), which described the elements present in the teaching and learning process that the teacher must take into account to develop a high-quality process for attention to diversity in the classroom (17 items); "Curricular and organizational response to diversity in the classroom" (Factor II), which analyzed the teacher's level of training to face students' educational needs in the classroom (8 items); "Pedagogical training for diversity" (Factor III), which evaluated the training received on Special Education in the Master's program (9 items); "Educational teaching practice in attention to diversity" (Factor IV), which analyzed how the training received enabled the preservice teacher to respond to the interests and concerns detected in students with SNES (5 items); and "Pedagogical perception of the student with SNES" (Factor V), which explored the preservice teachers' attitudes toward attention to diversity and response to the educational needs such attention required in the classroom in general (4 items). The point values for each factor ranged from 1 to 4 . The results were interpreted to consider values below 2.5 as agreement or more favorable and values above 2.5 as disagreement or less favorable. The average overall score ranged from 1 to 4 , such that the lower the score, the more favorable the opinion/attitude toward attention to diversity. The instrument showed good psychometric properties, with a Cronbach's Alpha of 0.92 for the global scale and ranging from 0.81 to 0.96 for the dimensions; and 0.85 for the study participants and ranging from 0.71 to 0.91 for the dimensions.

The instrument included some questions dedicated to gathering sociodemographic and academic information on the participants: sex (male or female), age, degree granting access to the MAES, specialization within the MAES and whether or not the participant had any type of disability. Additional variables of interest in prior studies, such as Polo et al. [71], were included: gender (feminine, masculine, and other, with an open response option); whether or not the participant had had contact with persons with disabilities and/or disorders; reasons for this contact (classmate, family member, co-worker, leisure/friendship, and/or other); frequency (almost never, rarely, often, very often) and quality of contact (very negative, negative, neutral, positive or very positive).

\subsection{Procedure}

To ensure reliable and responsible research, the study followed the ethical considerations established by the ethics committee of the research team's university (no. 1942/CEIH/2021). First, approval for the study was obtained from the coordinator of the Master's. On the last day of class in the course "Educational processes and contexts", the researchers informed the students of the study's objectives, telling them that participation was voluntary and anonymous, and the data confidential. The students then gave their informed consent. The procedure for accessing the online Google Forms questionnaire was explained and the access link handed out with a single-use numerical password. The instructions for completing the questionnaire were then read aloud (the instructions were also available in writing in the questionnaire), and the students had the opportunity 
to ask questions. The students then had an hour to complete the questionnaire. The researchers of the study were not part of the teaching staff who taught the compulsory subject "Educational processes and contexts" in mathematics' area which is the focus of this research.

\subsection{Design and Data Analysis}

A descriptive and transversal correlational-predictive study was performed [72] to assess the perceptions of the preservice teachers in the mathematics specialization concerning attention to diversity.

The data analysis used the statistical program SPSS 24.0 for Windows, with a $5 \%$ margin of error and a 95\% confidence level. Based on the objectives proposed for this study, descriptive analysis (mean and standard deviation) was performed first, as well as frequencies to characterize the sample and the students' perceptions about attention to diversity. Second, Kolmogorov-Smirnov and Levene's tests were performed to confirm normality and homoskedasticity of the sample. As no significant differences were found, the parametric test was used. Second, Pearson's correlation was calculated to determine the relationship among the different factors measuring perceptions of attention to diversity. Third, to study intergroup comparisons, $t$-tests were performed for independent samples and the univariate ANOVA with the Bonferroni multiple comparisons test to define the groups in which significant differences were observed. Estimations of the effect size were also performed by calculating Cohen's $\mathrm{d}$ and Eta squared (small: $0.20<\mathrm{d}<0.30$; medium: $0.30<\mathrm{d}<0.80$; and large: $\mathrm{d}>0.80$ ). Finally, stepwise multiple linear regression analysis was performed to determine the predictive character of Factors I, II, IV and V on pedagogical training in attention to diversity.

\section{Results}

\subsection{Descriptive and Correlational Study}

Table 2 presents the descriptive results of the students' perceptions of attention to diversity. The students agreed most strongly on the elements of the teaching-learning process that the teacher must take into account to develop high-quality attention to diversity $\left(\mathrm{M}_{\text {Factor I }}=1.41\right)$. They also shared a generally favorable perception and attitude toward diversity $\left(\mathrm{M}_{\text {Total }}=2.35\right)$. Students showed less agreement, however, on the other factors, which obtained values above 2.5 .

Table 2. Minimum, Maximum, Mean and Standard Deviation of students' perceptions of attention to diversity $(N=73)$.

\begin{tabular}{lcccc}
\hline \multicolumn{1}{c}{ Variables } & Minimum & Maximum & M & SD \\
\hline Factor I & 1 & 2.18 & 1.41 & 0.24 \\
Factor II & 1 & 4.00 & 2.61 & 0.68 \\
Factor III & 1.33 & 4.00 & 2.54 & 0.53 \\
Factor IV & 1.80 & 3.40 & 2.66 & 0.43 \\
Factor V & 1.25 & 3.75 & 2.55 & 0.56 \\
Total & 1.64 & 3.02 & 2.35 & 0.29 \\
\hline
\end{tabular}

Note: $\mathrm{M}=$ Mean; SD = Standard deviation.

The correlation analysis (Table 3 ) showed a positive and significant association among the elements conditioning the teaching-learning process that the teacher must take into account for high-quality attention to diversity (Factor I) and the pedagogical training acquired during the Master's (Factor III). The results also showed that the training received in the Master's to handle organizational and curricular response to diversity (Factor II) was positively and significantly related to the training received to respond to the interests and concerns of students with SNES (Factor IV) and to pedagogical training in matters of attention to diversity (Factor III). A positive and significant relationship was also obtained between pedagogical training received in the Master's to respond to students with SNES (Factor IV) and pedagogical training (Factor III). 
Table 3. Pearson correlation analysis between factors.

\begin{tabular}{lcccccc}
\hline & $\mathbf{1}$ & $\mathbf{2}$ & $\mathbf{3}$ & $\mathbf{4}$ & $\mathbf{5}$ & $\mathbf{6}$ \\
\hline 1.Factor I & 1 & & & & & \\
2.Factor II & 0.03 & 1 & & & & \\
3.Factor III & $0.26^{* *}$ & $0.43^{* *}$ & 1 & & & \\
4.Factor IV & 0.06 & $0.41^{*}$ & $0.67^{* *}$ & 1 & & \\
5.Factor V & -0.22 & -0.01 & -0.02 & -0.04 & 1 & 1 \\
6.Total & $0.21^{* *}$ & $0.74^{* *}$ & $0.80^{* *}$ & $0.72^{* *}$ & $0.32^{* *}$ & 1 \\
\hline
\end{tabular}

* The correlation is significant at level 0.05 (2-tailed); ** The correlation is significant at level 0.01 (2-tailed).

\subsection{Inferential Study}

Statistically significant differences based on the students sex and gender were confirmed for Factor I only; $t(64.14)=3.431, p<0.001, d=0.79$, with a moderate effect size. Men - participants who identified as masculine-showed a lower degree of agreement with statements in the questionnaire about elements of the teaching-learning process that the teacher must take into account to give appropriate attention to diversity (Table 4).

Table 4. Mean and standard deviation of perceptions of attention to diversity based on sex and gender.

\begin{tabular}{lcccc}
\hline \multirow{2}{*}{ Variables } & \multicolumn{2}{c}{ Men/Male $(\boldsymbol{N}=\mathbf{3 8})$} & \multicolumn{2}{c}{ Women/Female $(\boldsymbol{N}=\mathbf{3 5})$} \\
\cline { 2 - 5 } & $\mathbf{M}$ & $\mathrm{SD}$ & $\mathbf{M}$ & SD \\
\hline Factor I & 1.49 & 0.27 & 1.31 & 0.17 \\
Factor II & 2.69 & 0.66 & 2.52 & 0.70 \\
Factor III & 2.59 & 0.49 & 2.48 & 0.58 \\
Factor IV & 2.66 & 0.45 & 2.66 & 0.41 \\
Factor V & 2.55 & 0.53 & 2.56 & 0.60 \\
Total & 2.40 & 0.28 & 2.30 & 0.30 \\
\hline
\end{tabular}

Note: M = Mean; SD = Standard deviation.

Analysis to detect differences between the class sections that received the teaching produced statistically significant differences between groups and a medium effect size for Factor I; $t(71)=-3.029, p<0.01, d=0.74 ; \mathrm{IV}, t(71)=-2.983, p<0.01, d=0.69$; and Factor $\mathrm{V}$, $t(71)=-2.415, p<0.05, d=0.58$. The size was large for Factor III $t(71)=-5.013, p<0.001$, $d=1.17$; and for the Total $t(71)=-2.278, p<0.05, d=0.95$. The students of Professor A, who had more experience teaching in the MAES, agreed more strongly on the elements in the teaching-learning process needed for appropriate attention to diversity. They also assessed more favorably the education and pedagogical training for diversity acquired in the Master's and showed a more favorable attitude toward persons with disabilities (Table 5).

Table 5. Mean and standard deviation of perceptions of attention to diversity based on the professor.

\begin{tabular}{lcccc}
\hline \multirow{2}{*}{ Variables } & \multicolumn{2}{c}{ Professor A $(\boldsymbol{N}=\mathbf{3 5 )}$} & \multicolumn{2}{c}{ Professor B $(\boldsymbol{N}=\mathbf{3 8})$} \\
\cline { 2 - 5 } & $\mathbf{M}$ & $\mathbf{S D}$ & $\mathbf{M}$ & $\mathbf{S D}$ \\
\hline Factor I & 1.32 & 0.19 & 1.48 & 0.26 \\
Factor II & 2.57 & 0.61 & 2.64 & 0.74 \\
Factor III & 2.26 & 0.44 & 2.80 & 0.48 \\
Factor IV & 2.51 & 0.37 & 2.79 & 0.44 \\
Factor V & 2.40 & 0.58 & 2.71 & 0.49 \\
Total & 2.27 & 0.28 & 2.42 & 0.29 \\
\hline
\end{tabular}

Note: M = Mean; 0.95 () PONER EL \%, o como se indica arriba es redundantee; SD = Standard deviation.

Statistically significant differences related to whether the participant had a disability and / or disorder were found in Factor III; $t(71)=-2.793, p<0.01, d=0.67$; and Factor IV; $t(71)=-2.153, p<0.05, d=0.50$, with medium effect sizes. Students with disabilities (Table 6) agreed less with their pedagogical training to tackle diversity and with the training received in the Master's to respond to the interests and concerns of students with SNES. 
Table 6. Mean and standard deviation of perceptions of attention to diversity based on having or not having a disability.

\begin{tabular}{lcccc}
\hline \multirow{2}{*}{ Variables } & \multicolumn{4}{c}{ Disability/Disorder } \\
\cline { 2 - 5 } & \multicolumn{2}{c}{ No $(\boldsymbol{N}=\mathbf{3 2})$} & \multicolumn{2}{c}{ Yes $(\boldsymbol{N}=\mathbf{4 1})$} \\
\cline { 2 - 5 } & $\mathbf{M}$ & $\mathrm{SD}$ & 1.45 & SD \\
\hline Factor I & 1.35 & 0.23 & 2.66 & 0.25 \\
Factor II & 2.53 & 0.70 & 2.69 & 0.67 \\
Factor III & 2.35 & 0.57 & 2.75 & 0.46 \\
Factor IV & 2.54 & 0.45 & 2.48 & 0.39 \\
Factor V & 2.64 & 0.53 & 2.40 & 0.57 \\
Total & 2.29 & 0.31 & & 0.27 \\
\hline
\end{tabular}

Note: $\mathrm{M}=$ Mean; SD = Standard deviation.

Statistically significant differences were confirmed based on contact with persons with disabilities or disorders in Factor I; $t(36.57)=2.788, p<0.01$. $d=0.79$; and Factor III $t(71)=2.578 ; p<0.05, d=0.61$, with a moderate effect size in both cases. Students who had had contact with persons with disabilities or disorders (Table 7) agreed most strongly with the elements conditioning the process of attention to diversity in the classroom. They also believed they were better trained to tackle such attention.

Table 7. Mean and standard deviation of perceptions of attention to diversity based on contact.

\begin{tabular}{lcccc}
\hline & \multicolumn{3}{c}{ Contact } \\
\cline { 2 - 5 } \multicolumn{1}{c}{ Variables } & M & No $(N=29)$ & Yes $(N=44)$ \\
\cline { 2 - 5 } & 1.51 & SD & M & SD \\
\hline Factor I & 2.61 & 0.31 & 1.33 & 0.15 \\
Factor II & 2.70 & 0.68 & 2.60 & 0.69 \\
Factor III & 2.70 & 0.49 & 2.38 & 0.54 \\
Factor IV & 2.57 & 0.46 & 2.63 & 0.41 \\
Factor V & 2.41 & 0.44 & 2.54 & 0.63 \\
Total & 0.28 & 2.30 & 0.30 \\
\hline
\end{tabular}

Note: $\mathrm{M}=$ Mean; SD = Standard deviation.

Frequency of contact produced statistically significant differences in Factor I; $F(3.40)=3.068, p<0.05, \eta^{2}=0.433$; and in the Total; $F(3.40)=3.101, p<0.05, \eta^{2}=0.434$; with large effect sizes. The post hoc Bonferroni test showed that these differences occurred between students with almost no contact and the other groups (Table 8). The students with almost no contact agreed less strongly with the elements conditioning the teachinglearning process for providing high-quality attention to diversity. Overall, this group also had a more negative perception of attention to diversity.

Table 8. Mean and standard deviation of perceptions of attention to diversity based on frequency of contact.

\begin{tabular}{|c|c|c|c|c|c|c|c|c|}
\hline \multirow{3}{*}{ Variables } & \multicolumn{8}{|c|}{ Frequency } \\
\hline & \multicolumn{2}{|c|}{ Almost Never $(N=3)$} & \multicolumn{2}{|c|}{ Rarely $(N=16)$} & \multicolumn{2}{|c|}{ Often $(N=19)$} & \multicolumn{2}{|c|}{ Very Often $(N=6)$} \\
\hline & $\mathbf{M}$ & SD & $\mathbf{M}$ & SD & $\mathbf{M}$ & SD & $\mathbf{M}$ & SD \\
\hline Factor I & 1.57 & 0.19 & 1.31 & 0.13 & 1.33 & 0.13 & 1.29 & 0.17 \\
\hline Factor II & 3.17 & 0.56 & 2.49 & 0.62 & 2.54 & 0.79 & 2.81 & 0.47 \\
\hline Factor III & 2.96 & 0.17 & 2.38 & 0.46 & 2.37 & 0.51 & 2.72 & 0.75 \\
\hline Factor IV & 2.80 & 0.40 & 2.56 & 0.43 & 2.60 & 0.39 & 2.83 & 0.48 \\
\hline Factor V & 2.66 & 0.63 & 2.19 & 0.59 & 2.72 & 0.66 & 2.79 & 0.37 \\
\hline Total & 2.63 & 0.30 & 2.19 & 0.18 & 2.31 & 0.33 & 2.49 & 0.33 \\
\hline
\end{tabular}


The ANOVA confirmed that no significant interaction occurred among the perceptions based on either participants' age or quality of contact.

\subsection{Regression Analysis}

Finally, the potential predictors of pedagogical training in matters of attention to diversity were analyzed using multiple linear regression analysis. The predictor variables included were those related to training received in the Master's (Factors II and IV) and to elements conditioning the process of attention to diversity (Factor I). Factor V was not included in the analysis because it did not correlate with the criterion variable (see Table 3).

The indicators of tolerance and independence of the variables included in the regression equation were assessed. The tolerance indicator showed values between 0.83 and 1.00. The Variance Inflation Factor (VIF) took values between 1.00 and 1.20. These results enable dismissal of the possibility of error derived from collinearity (Hair et al., 2009). Similarly, the Durbin-Watson statistic took a value of 1.62, affirming independence of the data (Gil, 2003).

Table 9 presents the results of the stepwise analysis. The predictive capacity of the final model was sound, as the predictors explained $52.9 \%$ of the variance (Adjusted $\mathrm{R}^{2}=0.508$ ). The model was significant; $F(3.69)=25.822, p<0.001$, indicating that the relationship between pedagogical training and the set of predictors tested was statistically significant. As can be observed, Factor IV was the main predictor variable of pedagogical training in attention to diversity. It was followed by Factor I, with a positive predictive orientation, and Factor II in third place, with less weight and positive orientation. Better training and knowledge of the elements conditioning the teaching-learning process for high-quality attention to diversity thus predict more pedagogical preparation in matters of attention to diversity.

Table 9. Multiple linear regression model for pedagogical training for diversity.

\begin{tabular}{|c|c|c|c|c|c|c|c|c|}
\hline Predictors & $F$ & $R^{2}$ & B & SE & $\beta$ & $t$ & $p$ & $r$ \\
\hline Step 1 & & & & & & & & \\
\hline $\begin{array}{c}\text { Factor IV } \\
\text { Step } 2\end{array}$ & $57.971^{* * *}$ & 0.449 & 0.831 & 0.109 & 0.670 & 7.614 & 0.000 & 0.670 \\
\hline Factor IV & & & 0.815 & 0.105 & 0.657 & 7.751 & 0.000 & 0.670 \\
\hline $\begin{array}{c}\text { Factor I } \\
\text { Step } 3\end{array}$ & $34.775^{* * * *}$ & 0.498 & 0.487 & 0.187 & 0.222 & 2.612 & 0.011 & 0.260 \\
\hline Factor IV & & & 0.719 & 0.112 & 0.580 & 6.411 & 0.000 & 0.670 \\
\hline Factor I & $25.822^{* * *}$ & 0.529 & 0.485 & 0.112 & 0.220 & 2.662 & 0.010 & 0.260 \\
\hline Factor II & & & 0.151 & 0.071 & 0.191 & 2.114 & 0.038 & 0.432 \\
\hline
\end{tabular}

Note: ${ }^{* * *} p<0.001 ; \mathrm{B}=$ Unstandardized regression coefficients; SE = Standard Error; $\beta=$ Standardized regression coefficients; $r=$ Correlations.

\section{Discussion}

The importance and interest of this study of reflection on the initial training of preservice mathematics teachers concerning attention to diversity in the classroom stem from its consideration of the teacher as indispensable for attending to students' diversity in the classroom [4-8].

The results obtained generally confirm that students in the mathematics specialization have favorable perceptions of attention to diversity. More specifically, the students expressed more agreement on the elements of the teaching-learning process that the teacher must take into account to develop high-quality attention to diversity. Students agreed less strongly, however, with issues involving the teacher's education level to respond to the student's educational needs in the classroom (Curricular and organizational response to diversity in the classroom, Factor II), training received on special education in the Master's (Pedagogical training for diversity, Factor III), training received enabling the preservice teacher to respond to interests and concerns detected in students with SNES (Educational pedagogical practice in attention to diversity, Factor IV), preservice teachers' attitudes to 
attention to diversity and the response to the students' educational needs in the classroom in general (Teacher's perception of students with SNES, Factor V).

The students generally demonstrated good will toward developing a process for highquality attention to diversity capable of achieving full inclusion of students with SNES. This result contrasts with those in other studies $[19,20,73]$, which indicate that preservice teachers have difficulty adapting their practice to the diversity in their classrooms.

Including students with SNES in the current educational system is an urgent challenge that has caused and continues to cause much questioning and stumbling over various difficulties [74-76]. The students in the mathematics specialization hold that attention to diversity does not involve extra work for the teacher, even though the teacher must be responsible for both the support teacher responsible for integration and the tutor.

To achieve high-quality inclusion in schools, attention to diversity must be considered as a process that seeks identification and elimination of barriers throughout the teachinglearning process, and participation and success for all students, independently of their individual characteristics. To reach this goal, teachers must be able to attend to students and must thus receive education about the characteristics of students with SNES and the best way to include all students in the classroom [77,78], since teaching the discipline of mathematics itself is challenging for teachers, even for students without identified difficulties [10].

Most participants agreed as preservice teachers that developing a process of attention to diversity in the classroom required the school to attend to all students. Attention to diversity therefore played an important role in their teaching practice, although they recognized that truly achieving sufficient attention to diversity in secondary education could be a utopian goal. Despite considering it difficult to implement the approaches to attention to diversity proposed in current laws on education, the preservice teachers called special attention to the favorable attitude parents have to their children's education, as they believe that paying high-quality attention to diversity enriches the whole education community $[1,36,42]$.

Furthermore, the students did not agree completely in determining a series of issues conditioning the process of attention to diversity in the classroom. These issues include collaborative work among professionals, pedagogical motivation, family's attitude, support from administrative units, appropriate teacher-student ratio, etc. From this perspective, the MAES is conceived as a new educational opportunity for preservice secondary school teachers $[9,11,12]$ that can lead to the acquisition of more in-depth didactic and psychopedagogical knowledge that prepares teachers for their future professional practice in the classroom [79]. Forlin and Chambers [16], Sharma et al. [12] and Da Silva [37] argue, however, that teachers hold prejudices, beliefs and ideas prior to their daily classroom practice that can hinder this process. This obstacle merits attention, and Hernández and Carrasco [18] and Reoyo et al. [17] assert the vital importance of training teachers in curricular and affective issues and relational skills.

Nevertheless, the preservice teachers in mathematics believed that the training they received on curricular and organizational issues for diversity was not entirely sufficient for handling issues involving grouping of students, selection and adaptation of goals, basic contents and competences, measures and programs on attention to diversity provided by the Spanish education system, spatio-temporal organization, methodological strategies and design and assessment of activities. These results are related to those obtained by Flores and Villardón [15]. The preservice teachers in mathematics secondary education showed some knowledge gaps concerning the concept of attention to diversity, strategies and resources for integration and inclusion, methodological competences, and learning community environments. These results agree with those obtained in other studies $[6,9-11,13,15,42]$ highlighting the gaps in the initial training that preservice teachers had requested in secondary education on the content proposed $[6,13,14]$.

The purpose of the MAES is thus linked to increasing pedagogical training and sensitization to attention to diversity. This approach does not, however, contribute to or help 
preservice teachers to increase their interest in attention diversity or secure the student's choice in the teaching environment. Studies such as Reyes [14] and Mintos et al. [80] indicate the pedagogical factor as a key element for the transformation of education, calling for better professional preparation and development of instructors in the area of attention to diversity. Such training can overcome the daily challenges teachers face in their classroom activity $[4-7,78]$. It is thus crucial, among other actions, to foster and implement policies that enable professional development and improvement of teachers' working conditions, as well as to review training systems and key issues in the profession that arise with new social and cultural scenarios.

Further, better training and knowledge of the elements conditioning the teachinglearning process for high-quality attention to diversity predicted better pedagogical training in matters of attention to diversity. This study demonstrated that the content of the MAES and the training acquired in it are closely related to the knowledge acquired to organize the response to diversity in the classroom. It follows that the degree program contains elements that are encouraging in terms of training for higher-quality attention to diversity. In addition, it is significant that most of the preservice teachers considered their training in diversity as very important to their future teaching practice, even if they did not feel fully prepared in the knowledge acquired, improvement in their ability to be teachers, or their sensitivity to diversity. These data agree partially with similar studies $[16,72,79]$.

As for sociodemographic variables that influence the mathematics teachers' perceptions, the findings underscore the conclusion that the students who identified as feminine expressed more favorable attitudes to and knowledge about inclusive education than the students who identified as masculine-data that agree with other studies $[8,80]$.

The students showed different attitudes and training needs concerning inclusive education based on their instructor in the MAES. Students studying with the more experienced professor expressed greater agreement on the elements of the teaching-learning process for appropriate attention to diversity and evaluated their education and pedagogical training for diversity acquired in the Master's more highly. This group also showed a more favorable attitude to persons with disabilities. These results follow the lines of authors such as Avramidis and Norwich [9] and Crisol and Caurcel [8].

Finally, and significantly, the students with disabilities agreed to a lesser extent that their pedagogical training to tackle diversity and the training received during the Master's prepared them to respond to the interests and concerns of students with SNES.

Although most of the preservice teachers held positive attitudes and perceptions of inclusive education, those who had had experiences with people with functional diversitythat is, contact with persons with disabilities or disorders-demonstrated more positive attitudes and perceptions that those who had not had contact with persons with disabilities. Further, the preservice teachers who had had contact with people with functional diversity felt they were better trained to tackle it teaching students with SNES. Research shows [47-51] that contact with persons with disabilities increases positive attitudes toward these persons. Thus, students who have this experience show more favorable attitudes, specifically attitudes to the value of their capabilities, their degree of personal involvement, and their general evaluation of persons with disabilities. It would thus be very interesting for teachers to have contact with persons with disabilities during their training, whether through field work, volunteering or the practicum.

\section{Conclusions}

This study aimed to analyze the attitudes and perceptions of mathematics students in the MAES concerning initial training received on attention to diversity. As to the first objective, the results obtained enable us to conclude that the students had a generally favorable perception and attitude toward attention to diversity. For the second objective, a positive and significant association was observed between the elements conditioning the teaching-learning process that the teacher must take into account for high-quality attention to diversity and the training received to respond to the interests and concerns of students 
with SNES using the pedagogical training acquired during the MAES. As to the third objective, the findings show that men-respondents who identified as masculine- showed less agreement than did women with the elements of the teaching-learning process that the instructor must take into account for appropriate attention to diversity. The students who took the class "Educational Processes and Contexts" with the more experienced professor in the MAES valued more highly the pedagogical training and preparation for diversity acquired in the Master's and had a more favorable attitude to persons with disabilities. Contact with persons with disabilities influences perception. Overall, students with less contact had more negative perceptions of attention to diversity. Finally, the findings on the fourth objective showed that better training and knowledge of the elements conditioning the teaching-learning process for attention to diversity predicted better pedagogical training in matters of attention to diversity.

Finally, we should mention that pedagogical training (initial and continuing) must be considered as an instrument that can improve the educational attention the mathematics teacher pays to students with SNES, as Flores and Villardón [15] and Medina Sánchez and Pérez Valverde [78] recommend. The MAES is thus conceived as a new educational opportunity for preservice teachers in secondary education in matters of attention to diversity. This means that students are likely to support inclusive education more in performing their work as teachers if they have received specific training based on practical examples proposed and developed in classes than are teachers who have not received such training. They are also more likely to be more positive about inclusion, with a higher level of personal efficacy and lower levels of worry $[15,27,81]$. The educational administration should contribute to this confidence by encouraging processes of advanced and updated pedagogical training to respond to the needs and concerns of in-service teachers to guarantee school inclusion [82-84] and to the enactment of effective mathematics teaching [85].

This study's limitations are related to possible social desirability and sincerity in the self-report measures, although the study used standardized, validated instruments. To overcome this limitation, future research could develop mixed studies that include interviews with the MAES students to enable more in-depth exploration of their educational needs and training in matters of attention to diversity. The field of Social Sciences has limitations in the development of research studies, which is related to sample size. This study is cross-sectional in nature, since it only represents that sample in that moment. Additionally, the study was carried out only with students specialising in mathematics and through simple random probability sampling. A longitudinal study be interesting to perform longitudinal studies to determine the direction in which the perceptions and attitudes of the preservice mathematics teachers evolve once they begin their work as teaching professionals. Based on the results, it would also be interesting to perform studies that focus on the population of preservice professionals with SNES to explore in greater depth their perceptions of attention to diversity.

Author Contributions: Conceptualization, M.J.C.C., E.C.M. and C.d.P.G.-M.; methodology, M.J.C.C., E.C.M. and C.d.P.G.-M.; formal analysis, M.J.C.C. and E.C.M.; investigation, M.J.C.C. and E.C.M.; data curation, M.J.C.C., E.C.M. and C.d.P.G.-M.; writing—original draft preparation, M.J.C.C., E.C.M. and C.d.P.G.-M.; writing-review and editing, M.J.C.C., E.C.M. and C.d.P.G.-M.; visualization, M.J.C.C.; supervision, M.J.C.C. and E.C.M.; project administration, M.J.C.C. and E.C.M. All authors have read and agreed to the published version of the manuscript.

Funding: This research received no external funding.

Institutional Review Board Statement: The study was conducted according to the guidelines of the Declaration of Helsinki, and approved by the Ethic Committee of University of Granada (protocol no. 1942/CEIH/2021 date 9 February 2021).

Informed Consent Statement: Informed consent was obtained from all subjects involved in the study. 
Data Availability Statement: The data presented in this study are available on request from the corresponding author.

Conflicts of Interest: The authors declare no conflict of interest.

\section{References}

1. Castro, C.C.; Torres, E. La educación matemática inclusiva: Una experiencia en la formación de estudiantes para profesor. Infancias Imágenes 2017, 16, 295-304. [CrossRef]

2. Roos, H. Inclusion in Mathematics in Primary School. What Can It Be? Ph.D. Thesis, Linnaeus University, Smolan, Sweden, 2015.

3. Castro, C.; Torres, E.; Gil, D. Experiencias Educativas y Prácticas Pedagógicas en la Universidad Distrital; Fondo de Publicaciones Universidad Distrital: Bogotá, Colombia, 2013.

4. López-Torrijo, M.; Mengual-Andrés, S. An attack on inclusive education in secondary education: Limitations in initial teacher training in Spain. New Approach Educ. Res. 2015, 4, 9-17. [CrossRef]

5. Colmenero Ruiz, M.J.; Pantoja Vallejo, A.; Pegalajar Palomino, M.C. Percepciones del alumnado sobre atención a la diversidad en la formación inicial del profesorado de Educación Secundaria. Rev. Complut. Educ. 2015, 26, 101-120. [CrossRef]

6. Madariaga, J.M.; Huguet, A.; Japresta, C. Actitud, presión social y Educación Inclusiva en aulas con diversidad lingüística y cultural. Educ. XXI 2013, 16, 305-328. [CrossRef]

7. Alquraini, T. Factors related to teachers' attitudes towards the inclusive education of students with severe intellectual disabilities in Riyadh, Saudi. J. Res. Spec. Educ. Needs 2012, 12, 170-182. [CrossRef]

8. Crisol Moya, E.; Caurcel Cara, M.C. Percepciones de los estudiantes de la especialidad de lengua extranjera-inglés sobre atención a la diversidad en la formación inicial del profesorado de Educación Secundaria". Onomázein Spec. Issue VI Investig. Enseñanza Leng. Desde Una Perspect. Glob. 2020, 167-188. [CrossRef]

9. Avramidis, E.; Norwich, B. Teachers' attitudes towards integration/inclusion: A review of the literature. Eur. J. Spec. Needs Educ. 2002, 17, 129-147. [CrossRef]

10. Aké, L. Matemáticas y educación especial: Realidades y desafíos en la formación de profesores. In Educación Especial y Matemática Educativa; López-Mojica, J., Cuevas, J., Eds.; Universidad Autónoma de San Luis de Potosí, Centro de Estudios Jurídicos y Sociales Mispat: Mexico City, Mexico, 2015; pp. 15-32.

11. Carpenter, C.; Cai, S. Effect of clinic experience on pre-service professionals' perceptions of applied special needs services. Rev. Bras. Cineantrop Desemp Hum. 2011, 13, 145-149. [CrossRef]

12. Sharma, U.; Moore, D.; Sonawane, S. Attitudes and concerns of preservice teachers regarding inclusion of students with disabilities into regular schools in Pune, India. Asia Pac. J. Teach. Educ. 2009, 37, 319-331. [CrossRef]

13. Horne, P.; Timmons, V. Making it work: Teachers' perspectives on inclusion. Intern. J. Incl. Educ. 2009, 13, 273-286. [CrossRef]

14. Reyes, M.M. La formación del profesorado, motor de cambio en la escuela del siglo XXI. Rev. Educ. Incl. 2010, 3, 89-102. Available online: https:/ / revistaeducacioninclusiva.es/index.php/REI/article/view/175 (accessed on 14 June 2021).

15. Flores, L.; Villardón, L. Actitudes hacia la inclusión educativa de futuros maestros de ingles. Revista Latinoame. Educ. Incl. 2015, 9 , 63-75. Available online: http://www.rinace.net/rlei/numeros/vol9-num1/art3.pdf (accessed on 14 June 2021).

16. Forlin, C.; Chambers, D. Teacher preparation for inclusive education: Increasing knowledge but raising concerns. Asia-Pac. J. Teach. Educ. 2011, 39, 17-32. [CrossRef]

17. Reoyo, N.; Carbonero, M.A.; Freitas, A.; Valdivieso, J.A. La percepción de los futuros profesores sobre los docentes de Educación Secundaria. Int. J. Dev. Educ. Psychol. INFAD Rev. Psicol. 2012, 1, 389-396. Available online: http://hdl.handle.net/10662/2768 (accessed on 14 June 2021).

18. Hernández, M.J.; Carrasco, V. Percepciones de los estudiantes del Máster en Formación del Profesorado de Educación Secundaria: Fortalezas y debilidades del nuevo modelo formative. Enseñ. Teach. 2012, 30, 127-152. Available online: https:/ / revistas.usal.es/ index.php/0212-5374/article/view/9318 (accessed on 14 June 2021).

19. Vorming, D.O.E. Meta-Evaluatie M-Decreet. Synthese van Evaluatieve Publicaties Verschenen Sinds de Inwerkingtreding van het M-Decreet in 2015; Vlaanderen: Brussels, Belgium, 2017.

20. Smets, W.; Struyven, K.; Zhang, L.J. A teachers' professional development programme to implement differentiated instruction in secondary education: How far do teachers reach? Cogent Educ. 2020, 7, 1742273. Available online: https://doi.org/10.1080/2331 186X.2020.1742273 (accessed on 14 June 2021). [CrossRef]

21. Carmona, J.; Arango, C. Hacia una inclusión educativa en la enseñanza de las matemáticas. In Revista Científica 2013; Gallego, A., Ed.; Universidad Distrital Francisco José de Caldas: Bogotá, Colombia, 2013; pp. 636-640.

22. Nieminen, J.H.; Pesonen, H.V. Taking universal design back to its roots: Perspectives on accessibility and identity in undergraduate Mathematics. Educ. Sci. 2020, 10, 12. [CrossRef]

23. Goig Martínez, R.; Martínez Sánchez, I.; González, D.; García Llamas, J.L. Strategies for attention to diversity: Perceptions of secondary school teaching Staff. Int. J. Environ. Res. Public Health 2020, 17, 3840. [CrossRef]

24. Ponte, J.P. Mathematics teachers' professional knowledge. In Proceedings of the PME XVIII: Proceedings of the Eighteenth, University of Lisbon, Lisbon, Portugal, 29 July-3 August 1994.

25. Silverman, S.K. What is diversity? An inquiry into preservice teacher beliefs. Am. Educ. Res. J. 2010, 47, 292-329. Available online: https:/ / www.jstor.org/stable/40645442 (accessed on 14 June 2021). [CrossRef] 
26. Ponte, J.P.; Matos, J.F. (Eds.) Mathematics teachers' professional knowledge. In Proceedings of the Program Committee of the 18th PME Conference, Lisbon, Portugal, 29 July-3 August 1994; Volume I, pp. 195-210.

27. Turner, N.D. Preparing preservice teachers for inclusion in secondary classrooms. Education 2003, 123, $491-495$.

28. Boyd, B.; Bargerhuff, M.E. Mathematics education and special education: Searching for common ground and the implications for teacher education. Math. Teach. Educ. Dev. 2009, 11, 54-67. Available online: https://mted.merga.net.au/index.php/mted/ article/view/71 (accessed on 14 June 2021).

29. Roos, H. Inclusive Mathematics from a special education perspective: How can it be interpreted? In CERME 8: Congress of the European Society for Research in Mathematics Education; Ubuz, B., Haser, Ç., Mariotti, M.A., Eds.; Middle East Technical University: Manavgat-Side, Turkey, 2013; pp. 2860-2869.

30. Roos, H. Developing inclusion in mathematics: The impact of the principal. Paper Presented at the NORSMA Conference in Copenhagen 2013. 2014. Available online: https://edu.au.dk/fileadmin/edu/Forskning/Konferencer/Helena_Ross.pdf (accessed on 14 June 2021).

31. López-Mojica, J.M.; Ojeda, A.M. La formación matemática del docente de Educación especial: Una experiencia con estocásticos. In Formación Docente: Un Análisis Desde la Práctica; Carrillo, J., Ontiveros, V., Ceceñas, P., Eds.; Red Durando de Investigadores Educativos: Mexico City, Mexico, 2013; pp. 18-38.

32. Hill, H.C.; Ball, D.L.; Schilling, S.G. Unpacking pedagogical content knowledge of students. J. Res. Math. Educ. 2008, 39, 372-400.

33. Clarke, B.; Faragher, R. Inclusive practices in the teaching of mathematics: Supporting the work of effective primary teachers. In Proceedings of the 38th Annual Conference of the Mathematics Education Research Group of Australasia; Marshman, M., Geiger, V., Bennison, A., Eds.; MERGA: Sunshine Coast, Australia, 2015; pp. 173-180.

34. Torres, J.A.; Fernández, J.M. Promoviendo escuelas inclusivas: Análisis de las percepciones y necesidades del profesorado desde una perspectiva organizativa, curricular y de desarrollo profesional. Rev. Electrón Interuniv. Form. Profr. 2015, 18, 177-200. [CrossRef]

35. Avramidis, E.; Kalyva, E. The influence of teaching experience and professional development on Greek teachers' attitudes towards inclusion. Eur. J. Spec. Needs Educ. 2007, 22, 367-389. [CrossRef]

36. Pegalajar Palomino, M.C.; Colmenero Ruiz, M.J. Actitudes y formación docente hacia la inclusión en Educación Secundaria Obligatoria. REDIE Rev. Elect. Investig. Educ. 2017, 19, 84-97. [CrossRef]

37. Da Silva, M. Research Data in Education and in Visual Arts: Contribution for the construction of the Inclusive School. Rev. Lusóf. Educ. 2013, 25, 177-192. Available online: https://revistas.ulusofona.pt/index.php/rleducacao/article/view/4386 (accessed on 14 June 2021).

38. Lambe, J. Pre-service education and attitudes towards inclusion: The role of the teacher educator within a permeated teaching model. Int. J. Incl. Educ. 2011, 15, 975-999. [CrossRef]

39. Oliveira, M.A.; Freitas Souza, S. Policies for inclusion: Study in a State School in Belo Horizonte. Educ. Rev. 2011, 42, $245-261$. Available online: https:/ / www.scielo.br/pdf/er/n42/a16n42.pdf (accessed on 14 June 2021). [CrossRef]

40. García-García, M.; Biencinto-López, C.; Carpintero-Molina, E.; Núñez-del-Río, M.C.; Arteaga-Martínez, B. Rendimiento en matemáticas y actitud hacia la materia en centros inclusivos: Estudio en la Comunidad de Madrid. Rev. Investig. Educ. 2013, 31, 117-132. [CrossRef]

41. Torres, J.; Gaviria, Y. Una propuesta inclusiva para la representación grafico-geométrica de los poliedros con población ciega; Informe de pasantía de extensión para optar al título profesional de Licenciatura en Educación Básica con énfasis en Matemáticas; Universidad Distrital Francisco José de Caldas: Bogotá, Colombia, 2013.

42. Bermúdez, E.A.; Gutiérrez, H.; Wagner, G. Formación de profesores para una educación matemática en y para la diversidad. Sophia 2018, 14, 65-74. [CrossRef]

43. Pearse-Romera, C.R.; Ruiz-Cecilia, R.A. Motivation case study of students learning English at a secondary school in Granada, Spain. Int. J. Educ. Studies 2019, 14, 31-45. [CrossRef]

44. Sandoval Mena, M. Concepciones de los estudiantes de magisterio sobre la inclusión educativa. Aula Abierta 2009, 37, 79-88. Available online: https:/ / reunido.uniovi.es/index.php/AA/issue/view/1041/137 (accessed on 14 June 2021).

45. Monereo, C. La formación del profesorado: Una pauta para el análisis e intervención a través de incidentes críticos. Rev. Iberoam. Educ. 2010, 52, 149-178. [CrossRef]

46. Sanahuja, J.M.; Oscar Mas, O.; Olmos, P. El rol del profesorado de apoyo en el aula regular de un instituto de educación secundaria. Rev. Complut. Educ. 2018, 24, 943-959. [CrossRef]

47. Seo, W.; Chen, R.K. Attitudes of college students towards people with disabilities. J. Appl. Rehabil. Couns. 2009, 40, 3-8. Available online: https:/ / scholarworks.utrgv.edu/cgi/viewcontent.cgi?article=1014\&context=rhc_fac (accessed on 14 June 2021). [CrossRef]

48. García, G.A.; Hernández, S. Actitudes hacia la discapacidad de jóvenes y adultos de Chiapas. Univ. Psychol. 2011, 10, 817-827. Available online: http:/ / www.scielo.org.co/scielo.php?script=sci_abstract\&pid=S165792672011000300014\&lng=en\&nrm=iso\& tlng=es (accessed on 14 June 2021). [CrossRef]

49. Suriá-MArtínez, R. Análisis comparativo sobre las actitudes de los estudiantes hacia sus compañeros con discapacidad. Electr. J. Res. Educ. Psychol. 2011, 9, 197-216. Available online: http:/ /hdl.handle.net/11181/3635 (accessed on 14 June 2021). [CrossRef] 
50. Rodríguez-Martín, A.; Álvarez, E. Universidad y discapacidad: Actitudes del profesorado y de estudiantes. Perf. Educ. 2015, 37, 86-102. Available online: http:/ / www.scielo.org.mx/scielo.php?script=sci_arttext\&pid=S0185-26982015000100006 (accessed on 14 June 2021). [CrossRef]

51. Parasuram, K. Variables that affect teachers' attitudes towards disability and inclusive education in Mumbai, India. Disabil. Soc. 2006, 21, 231-242. [CrossRef]

52. Tomlinson, C.A. Teaching for excellence in academically diverse classrooms. Society 2015, 52, 203-209. [CrossRef]

53. Alghazo, E.; Naggar, E. General education teachers in the United Arab Emirates and their acceptance of the inclusion of students with disabilities. Br. J. Spec. Educ. 2004, 31, 94-99. [CrossRef]

54. Batsiou, S.; BeBetsos, E.; Panteli, P.; Antoniou, P. Attitudes and intention of Greek and Cypriot primary education teachers towards teaching pupils with special educational needs in mainstream schools. Intern. J. Incl. Educ. 2008, 12, 201-219. [CrossRef]

55. Opdal, L.R.; Wormnaes, S.; Habayeb, A. Teachers' opinions about inclusion: A pilot study in a Palestinian context. Inter. J. Disabil. Dev. Educ. 2001, 48, 143-162. [CrossRef]

56. Hodge, S.; Davis, R.; Woodard, R.; Sherrill, C. Comparison of practicum types in changing preservice teacher's attitudes and perceived competence. Adapt. Phys. Act. Q. 2002, 19, 155-171. [CrossRef]

57. Kudláèek, M.; Válková, H.; Sherrill, C.; Bettye Myers, B.; French, R. An inclusion instrument based on planned behavior theory for prospective physical educators. Adapt. Phys. Act. Q. 2002, 19, 280-299. [CrossRef] [PubMed]

58. Leyser, Y.; Rea, K. Evaluating inclusion: An examination of parent views and factors influencing their perspectives. Int. Disabil. Dev. Educ. 2004, 51, 271-285. [CrossRef]

59. Glaubman, R.; Hefziva, L. Ultra-orthodox Jewish teachers' self-efficacy and willingness for inclusion of pupils with special needs. Eur. J. Spec. Needs Educ. 2001, 16, 207-223. [CrossRef]

60. Avramidis, E.; Bayliss, P.; Burden, R. A survey of mainstream teachers' attitudes towards the inclusion of children with special educational needs in the ordinary school in one Local Education Authority. Educ. Psychol. 2000, 20, 193-213. [CrossRef]

61. Hastings, R.; Oakford, S. Student teachers attitudes towards the inclusion of children with special needs. Educ. Psychol. 2003, 23, 87-94. [CrossRef]

62. Bruno, A.; Noda, A. Necesidades educativas especiales en matemáticas: El caso de personas con síndrome de Down. In Investigación en Educación Matemática; Moreno, M., Estrada, A., Carrillo Sierra, J., Eds.; SEIEM: Lleida, Spain, 2010 ; pp. 141-162.

63. Bruno, A.; Noda, A.; Aguilar, R.; González, C.; Moreno, L.; Muñoz, V. Análisis de un tutorial inteligente sobre conceptos lógico-matemáticos en alumnos con Síndrome de Down. RELIME Rev Latin. Investig. Mat. Educ. 2006, 9, 211-226. Available online: https:/ / www.redalyc.org/pdf/335/33590203.pdf (accessed on 14 June 2021).

64. García, S.; Garnica, I. Comprensión de nociones de espacio y cantidad en aula de educación especial: Estudio de casos. In Acta Latinoamericana de Matemática Educativa; Flores, R., Ed.; CLAME: Mexico City, México, 2014.

65. Noda, A.; Bruno, A. Operaciones básicas en alumnos con síndrome de Down. PNA Rev. Investig. Didáct. Matem. 2010, 4, 143-159. [CrossRef]

66. Rosich, N.M.; Latorre, M.; Muria, S.; Jiménez, J. Diversidad y geometría en la ESO: El caso de alumnado deficiente auditivo. Contex Educ. Rev. Educ. 2006, 8-9, 51-68. Available online: http:/ / dx.doi.org/10.18172/con.557 (accessed on 14 June 2021).

67. Lambert, R. Indefensible, illogical, and unsupported: Countering deficit mythologies about the potential of students with learning disabilities in mathematics. Educ. Fac. Artic. Res. 2018, 8, 72. [CrossRef]

68. Lambert, R. When I am being rushed it slows down my brain: Constructing self-understandings as a mathematics learner. Int. J. Incl. Educ. 2017, 21, 521-531. [CrossRef]

69. Otzen, T.; Manterola, C. Técnicas de muestreo sobre una población a estudio. Int. J. Morphol. 2017, 35, 227-232. [CrossRef]

70. Colmenero Ruiz, M.J.; Pegalajar Palomino, M.C. Cuestionario para futuros docentes de Educación Secundaria acerca de las percepciones sobre atención a la diversidad: Construcción y validación del instrumento. Estudios Sobre Educ. 2015, 29, 165-189. [CrossRef]

71. Polo, T.; Chacón, H.; Caurcel, M.J.; Valenzuela, B. Attitudes towards persons with disabilities by educational science students: Importance of contact, its frequency and the type of disability. Int. J. Disabil. Dev. Educ 2020, 1-10. [CrossRef]

72. Hernández, R.; Fernández, C.; Baptista, P. Metodología de la Investigación, 5th ed.; McGrawHill: Mexico City, Mexico, 2010.

73. Healy, L.; Ferreira Dos Santos, H. Changing perspectives on inclusive mathematics education: Relationships between research and teacher education. Educ. Chang. 2014, 18, 121-136. [CrossRef]

74. Ainscow, M.; Susie, M. Desarrollando sistemas de Educación Inclusiva: ¿Cómo podemos hacer progresar las políticas? In La Educación Inclusiva. De la Exclusión a la Participación de todo el Alumnado; Climent, G., Ed.; Horsor: Barcelona, Spain, 2009; pp. 161-170.

75. Colmenero Ruiz, M.J.; Pegalajar Palomino, M.C. Capacitación docente para la atención a la diversidad en futuros docentes de educación secundaria. Rev. Ciènc. l'Educació 2014, 1, 83-96. [CrossRef]

76. González-Gil, F.; Martín-Pastor, E.; Poy, R. Educación inclusiva: Barreras y facilitadores para su desarrollo. Análisis de la percepción del profesorado. Profesorado 2019, 23, 243-263. [CrossRef]

77. Toboso, M. Sobre la educación inclusiva en España: Políticas y prácticas. Intersticios Rev. Sociol. Pensam. Crítico 2012, 6, $279-295$. Available online: http:/ / www.intersticios.es/article/view/10048 (accessed on 14 June 2021). 
78. Medina Sánchez, L.; Pérez Valverde, C. Adaptaciones metodológicas en el aula de lengua extranjera para el alumnado con discapacidad intelectual leve: Estudio de caso. Porta Linguarum 2017, 2, 267-282. Available online: https:/ / dialnet.unirioja.es/ servlet/articulo? codigo $=6736107$ (accessed on 14 June 2021).

79. Buendía, L.; Berrocal, E.; Olmedo, E.; Pegalajar, M.; Ruiz, M.; Tomé, M. Valoración por parte del alumnado de las competencias que se pretenden conseguir con el Máster Universitario de Profesorado en Educación Secundaria Obligatoria, Bachillerato, Formación Profesional y Enseñanza de Idiomas. Bordón. Rev. Pedagog. 2011, 63, 57-74. Available online: https://dialnet.unirioja. es/servlet/articulo?codigo=3712020 (accessed on 14 June 2021).

80. Mintos, A.; Hoffman, A.J.; Kersey, E.; Newton, J.; Smith, D. Learning about issues of equity in secondary mathematics teacher education programs. J. Mathem. Teach. Educ. 2019, 22, 433-458. [CrossRef]

81. O'Toole, C.; Burke, N. Ready, willing and able? Attitudes and concerns in relation to inclusion amongst a cohort of Irish pre-service teachers. Eur. J. Spec. Needs Educ. 2013, 28, 239-253. [CrossRef]

82. DeSimone, J.R.; Parmar, R.S. Issues and challenges for middle school mathematics teachers in inclusion classrooms. Sch. Sci. Math. 2010, 106, 338-348. [CrossRef]

83. Díez-Palomar, J.; Flecha Fernández de Sanmamed, A.; García-Carrión, R.; Molina-Roldán, S. Pathways to equitable and sustainable education through the inclusion of Roma students in learning mathematics. Sustainability 2018, 10, 2191. [CrossRef]

84. Sevilla, D.; Martín, M.; Jenaro, C. Percepciones sobre la educación inclusive: La vision de quienes se forman como docentes. Rev. Investig. Educ. 2017, 25, 83-113. Available online: http://www.scielo.org.mx/pdf/cpue/n25/1870-5308-cpue-25-00083.pdf (accessed on 14 June 2021).

85. NCTM. Principles to Actions: Ensuring Mathematical Success for All; National Council of Teachers of Mathematic: Reston, VA, USA, 2014. 